\title{
INFORMATION AND COMMUNICATION TECHNOLOGY SKILls' SufFICIENCY OF EgYPTIAN ACCOUNTING GRADUATES
}

\author{
Dr. Mohamed Elsaadani, PhD \\ Assistant Professor, the Arab Academy for Science \& Technology \& Maritime Transport
}

\begin{abstract}
This study aims at evaluating the sufficiency of ICT skills of fresh accounting graduates by soliciting the opinion of senior accounting professionals. A questionnaire used as the data collection method, and descriptive statistics used for analysis. The result of this research was surprisingly, as the level of the accounting graduates rated to be above average and they are very competent for current accounting profession in Egypt. The research revealed that any fresh graduate should be literate with Internet, word processing software, spreadsheet software, e-mail, commercial accounting software, and database management software. The research has several practical implications as well as a genuine value, as it provides current set of ICT skills tools needed by accounting profession in Egypt. Also, it calls accounting higher education institutions worldwide to keep investigating the requirements of the profession in order to produce graduates who are competent and up to market challenges.
\end{abstract}

\section{KEYWORDS}

Sufficiency, skills, ICT, Egypt, Accounting Graduates, HEI

\section{INTRODUCTION}

Literature on the sufficiency of acquired information and communication technology (ICT) skills of fresh accounting graduates, in developing countries in general and in Egypt in particular, is very limited [1] - [2] - [3] - [4]. Little is known about whether fresh accounting graduates are prepared with the right set of ICT skills in order to meet the needs of business organizations. This research has emerged to fill this gap in the literature.

Among the most affecting factors those promoting wide economic growth in the economy is ICT [5]. ICT uses in education and training have been a main concern because it has a major impact on both people involved in this process - students and teachers - as well as on the educational institutions themselves. Educational institutions who adopted ICT into the curriculum have demonstrated a high level of support for teaching and learning activities in many subject areas. These institutions have learned that ICT is not an end in itself, but should be used as a means to support creativity and generate efficient learners and future decision makers [6].

This is supported by the view of several other studies, which declared that ICT positively improve quality of learning and achieve strong educational outcomes [7] - [8]. In the same context, several studies [9] - [10] declared that ICT is an important part of education that can be used to raise life and workplace skills as well. Moreover, the literature stressed the enormous effects ICT

has on education, as ICT results in positive improvement for the quality of teaching and learning, thus educational institutions gaining great results [11].

DOI : 10.5121/ijait.2015.5201 
In the same context, department for education and skills declared in its report towards a unified elearning strategy that ICT is capable of supporting new ways of teaching and learning [12]. This is supported by a recent group of researches, as Reynolds et al. [13] declared that ICT may raise education standards, also Bruce [14] showed that ICT can enhance learning experiences and possibilities, [15] has found that ICT can enhance and transform the curriculum, while [16] indicated that ICT can result in positive impacts on achieving high order learning.

Literature revealed that there is a need for integrating ICT with education, Pombo et al. [17] declared that there is a need to provide students with the required skills needed by the professional practices, and also to equip and prepare teachers in order to be able to present to their student the right educational practices that is directed and integrated with these skills and experiences. This is the way students will be able to face the challenges of the fast changing professional environment. Moreover, Yang [18] determined that the most effective tool for educational renovation is the use of the right ICT tools, as ICT will be used as the medium for equipping professional with the required skills. In the current information age, ICT has always played a growing role in transforming societies. Earlier, Papert [19] recognized that ICT is an important medium for equipping students with the required skills needed to survive in this new information age.

On the other hand, Balanskat et al. [20] declared that some countries are in the early stages of adopting ICT in education still without any profound enhancements in learning and teaching. This is why countries should employ successful and strong ICT strategies in order to gain positive results in this regard [21].

\section{ICT AND ACCOUNTING EDUCATION}

ICT integration in education can result in significance effects by developing students' learning with new set of skills [22]. This is because ICT constitute an important medium especially for accounting students to acquire valuable skills needed by accounting profession [23]. Moreover, the use of ICT in educational programs can help students to learn more effectively [24], and also it can promote student learning outcomes and inspire their motivation, and through this encouragement it is eventually enhance students' enduring learning [25].

ICT literacy and skills are important factors in the current information era. A great attention has been given to education in response to the growing shift towards knowledge based communities, which require a supply of skilled graduates, who are well-prepared to be knowledgeable users of ICT tools [26]. This is due to the reason that ICT is going to change and transform the way students can learn and communicate in their educational and private lives [27].

Knowledge economy requires knowledge workers who are able to utilize ICT in their personal and professional lives, and the most important tool that can be used to prepare them during education stages is ICT. Thus, academic institutions have to adopt ICT in their teaching and learning as response for the requirements of new knowledge economies.

Regarding the use of ICT tools in accounting education, this will develop important technological capabilities, and fostering a competent learning environment based on important skills such as communication, interpersonal skills, and critical and analytical thinking skills [28]. Also, Valentine et al. [29] declared that ICT skills can equip students with the required knowledge and skills as well as gaining them with confidence and motivation. 
The literature showed that the speed of the technological changes and its adoption by business organizations is not matching the degree of developing professionals' skills [30]. Myunghee et al. [31] has indicated that a variety of attempts have been made to implement ICT to promote learning in different educational settings. Tudor et al. [32] discovered that majority of business organizations have stressed the importance of adopting ICT in accounting education in particular.

The literature indicated that accounting education has not been changed in a matching way to the profession itself, which have changed to incorporate a greater use of ICT [33], as a result, accounting education require the integration of ICT in order to close this gap. This delay in the development in accounting education created a gap in the knowledge and skills of accounting graduates, which will be obvious when they move forward to professional organizations as accountants [34] - [35] - [36].

Also, a recent study revealed that accounting graduates showed a low level of various soft skills as well as ICT skills, including graduates. Business organizations struggle to acquire knowledgeable and skillful professionals as a response for the ever changing business environment. Business organizations are facing various transitions; current workforce needs to have special knowledge and skills in order to be competent in these new environments, workforce in need for special training and education preparation before graduation [37].

In a different study, Lai [38] examined the situation of ICT readiness and level of self-efficacy of accounting students. The results revealed that they were neither techno-ready nor highly technoresistant, they had a moderate level of internet self-efficacy and computing experience. Therefore, educators should be more innovative in integrating ICT successfully in teaching and learning.

In the same context, Wessesls [37] when studied the issue of ICT offered to accounting students has found that the cause of the identified gap between the skills acquired by accounting graduates and the required level needed by the profession itself as due to the limited use of accounting software packages during their study period. This result was asserted by Rhodes [35] in her study about the required integration of ICT into accounting education. Both studies asserted that there is a need for a better integration of accounting software packages into accounting education based on the needs and the requirements of the profession itself, which will result in a more productive learning experience that is matching to the needs of workplace. Rhodes [35] suggested two improvements in order to successfully integrate the skills required by accounting profession into accounting education. The first improvement is to design a group of prepared practices designed for the teaching staff. The second improvement is to integrate the necessary tools those will help achieving the standards represented in any accounting topic. The two improvements are mutually support the success of the integration process.

In the same line of research, a group of research studies have been conducted worldwide regarding the analysis of the adequacy of the acquired skills in the accounting education. In a study for the US accounting graduates, Schwartz and Stout [39] has found that the preparation was minor as the fresh graduates were not well prepared with the sufficient skills required by the profession itself. These studies were aligned with studies of Miller and Woods [40], who analyzed UK accounting proficiency, and Tan and Veal [41], who analyzed New Zealand accounting proficiency, both studies discovered that graduates were not equipped with the required skills needed by the accounting profession in these countries. In the same context, Juchau and Neale [42] declared that accounting education should integrate the profession knowledge and skills in order to meet the requirements of accounting practices in Australia. Accounting programs should be improved by adopting ICT that will support the achievement of the skills needed by current business world. Accounting programs needs to be supported with ICT as tools for teaching, learning and communicating. Although accounting curriculum has some 
computerized products, they are not sufficient nor matched to business challenges [43]. This same opinion is shared by [44] Egbri who declared that ICT in the educational system have been underutilized and insufficient. Moreover, Egbri stated that even when we find some adoption of ICT, there may be lack of some ICT tools or lack of prepared educators with sufficient skills to adopt it efficiently. This was asserted by the result of earlier researches [42] - [45] - [46].

Several studies revealed that existing accounting programs failed to provide accounting graduates with necessary knowledge and skills needed to perform competently in accounting profession [38] - [42] - [47]. Moreover, USA accounting professionals emphasized that accounting graduates has to be prepared with a high level of technical and non-technical skills; this has to be combined with sufficient ICT skills [48] - [2].

Accounting profession worldwide keep adopting several accounting management systems, thus accounting graduated has to be ICT literate in order to meet business environment challenges [48] - [49]. This was in line with the study of Dresnack and Briggs [50], who declared that accounting graduates has to be prepared in order to match the dynamic business environment and they have to be equipped with the right accounting ICT skills.

The literature suggested that in order to meet the requirements of the accounting profession in the current fast changing business environment, accounting education has to be redesigned and developed to include skills and knowledge suitable for these new circumstances. Among the most important needed skills are ICT skills [41] - [51] - [52].

ICT skills has been determined as one of the most important required skill for accounting graduates by a group of international accounting associations. American Assembly of Collegiate Schools of Business (AACSB) declared the need for equipping accounting professionals with ICT tools and skills [53]. In the same context, The Institute of Management Accountants (IMA) has declared that among the required top 10 accounting profession skills is ICT [54]. Also, the American Institute of Certified Public Accountants (AICPA) recommends that learning the suitable ICT tools for the accounting profession is a primary objective [55].

Moreover, The American Accounting Association (AAA) has determined ICT as one of the most important tools required for accounting professionals [56]. In addition to this, Accounting Education Change Commission (AECC) has declared that accounting professionals has to be equipped with ICT tools and skills in order to successful and competent in the rapidly growing technological business environment [57]. Also, International Federation of Accountants Education (IFAC) has determined that ICT is imperative for the Accounting Profession, and it is very important to integrate ICT into accounting education [58].

Today's accounting graduates has to be equipped with particular group of skills in order to be successful and competitive in working environments. ICT skills considered as one of the most important skills in this regard because of the rapid advancements in ICT and its high adoption by professional organizations [52].

The literature includes several researches those investigated the required ICT tools that can be used to enhance teaching and learning of business courses. Nneka and Festus [9] declared that there are some ICT tools those will change teaching and learning as well as changing the responsibilities of accounting teachers and their students; among these tools are: internet, video conferencing, databases, computer information systems, networking, and teleconferencing. This result asserted earlier via the research of Chen et al. [59]. Sanusi [60] in the same context recommended that educational institutions should adopt ICT tools those will enable teachers and students to use the internet, e-mail, and collaborative software. Educational institutions will not 
find competitive progress in their education activities unless they adopt these tools as well as the most recent technological innovations in teaching and learning activities.

In the same line of studies aimed at discovering the required skills of accounting graduates, several research studies have been made in this regard. Stoner [61] declared that the most required ICT skills for accounting students upon their entry to higher education are knowledge about using e-mail and the internet, then during their study they should acquire knowledge and skills about spreadsheets and work processing software. Stoner stressed that these four ICT skills represent the essential set of skills required for accounting graduates.

While, Burnett [62] surveyed managers and accounting professionals in order to discover the important skills required for accounting graduates. Burnett discovered that windows, spreadsheet, and word processing software were the top three important technology skills for new accounting hires. With reference to studies of [2] - [52], one of the central ICT skills for accounting graduates in the ability to use a type of accounting software.

\section{RESEARCH METHODOLOGY}

This research took place during the period from August 2014 to February 2015. Senior accounting professionals working in Egyptian business organizations are the main population of current research, their views are very important and appropriate regarding the level of sufficiency of ICT skills of fresh accounting graduates joining business organizations as junior accounting staff. Senior accounting professionals examined in this study are exists in several organizational levels as managers, supervisors, and senior staff. Current study excluded junior staff, as the investigation directed to collect data about their level of ICT skills sufficiency. Current research set four years of experience as criteria for considering an accounting professional as senior staff member.

Simple random cluster sampling was used for the selection of the participating business organizations located in Alexandria city of Egypt. The population of the study was senior accounting professionals working in accounting departments. The target participating commercial business organizations were chosen randomly based on the list of commercial business organizations obtained from "Yellow Pages - www.yellowpages.com" as a commercial business directory.

Thirty nine randomly selected organizations reported that they have a number of 234 managers, supervisors, and senior staff working in accounting departments at various levels. A questionnaire adopted from [49] was used as the data collection method after modifications in order to suite current study. 234 questionnaires were distributed, but only 188 were collected, and all the collected questionnaires were completed and usable, thus will be considered as the study sample, which represent $80.3 \%$ response rate.

When an instrument is accurate and consistent, it is supposed to have a high degree of reliability [63]; thus, minimizing the errors and biases in a research study [64]. Expert comments were used to check the validity of the instrument used. Research instrument was presented to 11 experts, who were asked to review and give their feedback, and then the instrument was evaluated and revised with their comments. The reliability of the questions was calculated as $73 \%$ using Cronbach's Alpha coefficient and confirmatory factorial analysis.

Statistical Package for Social Science (SPSS) program was used in coding and analyzing the data in light of the questions of study instrument. The probability level for a test of statistical 
significance for the study is $\mathrm{p}<.05$, to ensure $95 \%$ confidence in generalization of the findings. Descriptive statistics were used for data analysis of the collected data.

The instrument based on Likert scale ranging from very poor (1) to very good (5). Instrument consists of three parts, part 1 aimed at collecting demographic information about senior accounting professionals participating in the study, such as age, gender, position, years of experience, academic and professional qualifications earned. Part 2 aimed at soliciting their opinion regarding the most important ICT skills a fresh graduate should posses before start working with them as junior accountant staff member, while part 3 aimed at soliciting their level of satisfaction regarding the sufficiency of ICT skills of fresh accounting graduate joining them as junior accounting staff member.

A contact was made with the list of the participating business organizations in order to obtain their approval to start distributing the questionnaire and get their responses. Three follow-up contacts were made in order to ensure the readiness of questionnaires for collection.

\section{DATA ANALYSIS}

Table 1 shows the basic demographics of study sample, which was the first part of the study's instrument. Out of the 188 respondents, $32 \%$ were accounting managers, $27 \%$ were accounting supervisors, whilst $41 \%$ were accounting senior staff members. $68 \%$ of the respondents were males, while $32 \%$ were females. $12 \%$ of the participants were below 30 years old, whilst $88 \%$ were above 30 years old.

Almost $73 \%$ of the participants have been in the accounting profession for more than 10 years, these experienced professionals were appropriate candidates to assess the required ICT skills level required by fresh accounting graduates. Whilst $27 \%$ of the respondents have been in the accounting profession for less than 10 years, but more than 4 years, which was the research criteria to consider as senior accounting staff member.

Regarding the supervision frequency, almost all of the participants had staff under their supervision with varying numbers. $21 \%$ of the participants had more than 25 staff under their supervision, $52 \%$ had between 15 and $25,19 \%$ had between 5 and 10, whilst $8 \%$ had less than 5 staff under their supervision.

Table 1: Demographics of Respondents

\begin{tabular}{|l|c|c|}
\hline Demographics & Frequency & $\%$ \\
\hline Job Position \\
\hline Accounting Manager & 60 & 32 \\
\hline Accounting Supervisors & 50 & 27 \\
\hline Accounting Senior Staff & 77 & 41 \\
\hline Gender & \multicolumn{2}{|l|}{} \\
\hline Male & 128 & 68 \\
\hline Female & 60 & 32 \\
\hline Age & 23 & 12 \\
\hline Below 30 years & 165 & 88 \\
\hline Above 30 years & \\
\hline Years of Experience & 51 & 27 \\
\hline$>4$ \& < 10 years & 137 & 73 \\
\hline$>10$ years \\
\hline Supervision & 39 & 21 \\
\hline$>25$ staff
\end{tabular}




\begin{tabular}{|l|l|c|}
\hline $15: 25$ staff & 98 & 52 \\
\hline $5: 10$ staff & 36 & 19 \\
\hline$<5$ staff & 15 & 8 \\
\hline
\end{tabular}

Part two of study's instrument is regarding the most important ICT skills accounting graduate should possess, the study revealed that almost all surveyed senior accounting professionals agreed that any fresh graduate should be literate with Internet, word processing software, spreadsheet software, and e-mail (as shown in table 2). The study revealed as well that it is important for fresh graduates to have skills in this set of ICT tools: e-mail, commercial accounting software, and database management software. This result is in line with other research studies [2] - [9] - [52] [60] - [61] - [62], in which all agreed that fresh graduates needs these ICT tools in order to be competent in work environments. In addition to this set of ICT tools, fresh graduates are expected to have knowledge regarding commercial accounting software, as well as database management systems.

Table 2: important ICT skills an accounting graduate should possess

\begin{tabular}{|l|c|c|}
\hline & \multicolumn{2}{|c|}{ Mean Scores \& Rank } \\
\hline ICT Skills & Mean & Rank \\
\hline Spreadsheet software, i.e. MS Excel & 4.63 & 1 \\
\hline Word processing software, i.e. MS Word & 4.51 & 2 \\
\hline Internet & 4.14 & 3 \\
\hline E-mail & 3.85 & 4 \\
\hline Commercial accounting software, i.e. Peachtree* & 3.62 & 5 \\
\hline Database management software, i.e. MS Access & 3.29 & 6 \\
\hline
\end{tabular}

* Peachtree is the major example of commercial accounting software taught in accounting courses in Egyptian universities at the time of study.

Part three of study's instrument is regarding participants' evaluation of fresh accounting graduates' ICT skills. 56\% rated fresh accounting graduates' ICT skills to be "excellent", $17 \%$ rated them to be "very good", $21 \%$ rated them to be "good", $4.5 \%$ rated them to be "average", whilst $1.5 \%$ rated them to be "poor". This result is not the same as group of researches [33] - [37] - [38] - [39] - [40] - [41] - [42] - [43] - [44] - [47], in which they rated accounting graduates' ICT skills as poor and not adequate to the industry requirements.

Senior accounting staff reported using additional comments in the study's instrument that they concentrate their selection on the graduates of the private accounting higher institutions, and they may select among the graduates of the governmental accounting higher institutions only if the candidates are well prepared and trained during or after graduation to use the necessary ICT skills tools; this is because the use and preparation of these ICT skills tools in these governmental accounting institutions is poor.

\section{IMPLICATIONS OF STUDY}

The output of this research has practical implications. The first to the management of business organizations worldwide, private Egyptian accounting universities' fresh graduates are competent to match current business environment challenges from a technological point of view, as they possess the required basic ICT tools set needed to start working in the current information and knowledge era. Senior accounting professionals when asked about their evaluation of fresh accounting graduates' ICT skills, their evaluation was surprising, as the majority of them rated 
them to be above average and they were competent to be hired as junior staff member, as they were ready to work and were equipped with the necessary set of ICT skills tools.

The second implication to the management of the governmental accounting higher institutions in Egypt, they have to incorporate the required and determined ICT skills tools by senior accounting professional staff into accounting education at their universities. It is very important to prepare accounting graduates to use the recommended ICT skills tools by this research.

The third implication to the management of the accounting higher institutions in Egypt, by having more understanding on the requirements of the accounting profession, accounting HEI would be able to prepare their accounting graduates with the needed technical competencies as well as the basic theoretical principles. These HEI have to keep investigating the profession in order to have this understanding.

The fourth implication to the accounting educators, they have to be well prepared for teaching and learning their students using the recommended set of ICT skills tools. The fifth implication to the students of the accounting HEI, especially the governmental ones, in order to be competent in the current working environment they have to be well prepared for the knowledge economy they will be employed in after graduation. This research gives them the determined set of ICT skills tools they have to be equipped with in order to survive in the accounting profession.

\section{CONCLUSION}

The results of this research were surprisingly, as the level of the private accounting HEI in preparing their graduates is very competent for the current accounting profession in Egypt. This is very important as we are now in the time of ICT, and accounting graduates should be equipped with the appropriate set of skills in order to be competent in meeting the challenges of current working environment, and to be considered as knowledge workers as well.

Accounting HEI - private and governmental - has to be aware of the profession requirements all the time in order to deploy the appropriate set of technical and theoretical skills.

This research has value as it provides with the current required set of ICT skills tools needed by the profession in Egypt. Moreover, it provides an important vision for accounting HEI to keep examining the changing needs of the profession in order to keep up to date with its requirements so that graduates will be competent and up to the market challenge.

Further research studies have to be made in order to keep up to date with the requirements of the industry requirements for the accounting profession all over the world.

\section{RESEARCH LIMITATION}

This research has limitation as it represents a cross-sectional analysis, which involves the analysis of data collected from a study sample at one specific point in time. Thus, responses of the participants may change over time. Therefore, attention should be taken in generalizing current research findings over time, unless current research results will be asserted via further research studies.

\section{REFERENCES}

[1] Ismail, N.; Tayib, M.; Salim, B. (2005). IT Integration in Accounting Education: Are We Ready? Accountants Today, 18(7), pp. 36-39. 
International Journal of Advanced Information Technology (IJAIT) Vol. 5, No. 1/2, April 2015

[2] Greenstein, M.; McKee, T. (2004). Assurance practitioners' and educators' self-perceived IT knowledge level: an empirical assessment. International Journal of Accounting Information Systems, 5(2), pp. 213-43.

[3] Lin, Z. (2008). A Factor Analysis on Knowledge and Skill Components of Accounting Education: Chinese Case. Advances in Accounting, incorporating Advances in International Accounting, 24, pp. $110-118$

[4] Celik, O; Ecer, A. (2009). Efficiency in Accounting Education: Evidence from Turkish Universities. Critical Perspectives on Accounting, 20(5), pp. 614-634.

[5] Aristovnik, A. (2012). The impact of ICT on educational performance and its efficiency in selected EU and OECD countries: a non-parametric analysis. ICICTE 2012 Proceedings, pp. 551-524.

[6] Elsaadani, M. 2014. Influence of ICTs on workforce productivity in Egyptian industrial organizations. International Journal of Advanced Information Technology (IJAIT), 4(3), pp. 1-8.

[7] Yusuf, M.; Afolabi, A. (2010). Effects of computer assisted instruction (CAI) on secondary school students' performance in biology. The Turkish Online Journal of Educational Technology, 9(1), pp. 62-69.

[8] Shaikh, Z. (2009). Usage, acceptance, adoption, and diffusion of information and communication technologies in higher education: a measurement of critical factors. Journal of Information Technology Impact (JITI), 9(2), pp. 63-80.

[9] Nneka, E; Festus, A. (2014). Integrating Information and Communication Technology (ICT) in Accounting Education Instruction in Ekiti State Universities. International Journal of Business and Social Science, 5(6).

[10] Nwosu, B.; Ogbomo, N. (2011). ICT in Education: A Catalyst for Effective use of Information. PNLA Quarterly. The Official Publication of the Pacific Northwest Library Association, pp. 1-6.

[11] Buba, M. (2011). Integrated information and communication technology in the curriculum of Business Education. Journal of Business Educational Research and Development (JOBERD), 2(10), pp. 126-132.

[12] Department for Education and Skills (DfES). (2003). Towards a unified e-learning strategy. Nottingham: DfES Publications.

[13] Reynolds, D.; Treharne, D.; Tripp, H. (2003). ICT - The hopes and the reality. British Journal of Educational Technology, 34, pp. 151-167.

[14] Bruce, C. (2004). Information literacy as a catalyst for educational change: A background paper. In Danaher, P. (Ed.), Lifelong learning: Whose responsibility and what is your contribution? The 3rd International Lifelong Learning Conference, (13-16 June 2004) (pp. 8-19). Yeppoon, Queensland: Sage.

[15] Proctor, J.; Burnett, P.; Finger, G.; Watson, G. (2006). ICT integration and teachers' confidence in using ICT for teaching and learning in Queensland state schools. Australasian Journal of Educational Technology, 22, pp. 511-530.

[16] Pearson, M.; Somekh, B. (2006). Learning transformation with technology: A question of sociocultural contexts? International Journal of Qualitative Studies in Education, 19, pp. 519-539.

[17] Pombo, L.; Smith, M.; Abelha, M.; Caixinha, H.; Costa, N. (2012). Evaluating an online e-module for Portuguese primary teachers: trainees' perceptions, Technology, Pedagogy and Education. Technology, Pedagogy and Education, 21(1), pp. 21-36.

[18] Yang, H. (2012). ICT in English schools: transforming education? Technology, Pedagogy and Education, 21(1), pp. 101-118.

[19] Papert, S. (1980). Mindstorms: Children, computers and powerful ideas. New York, NY: Basic Books.

[20] Balanskat, A.; Blamire, R.; Kefala, S. (2006). The ICT impact report: a review of studies of ICT impact on schools in Europe. Brussels: European Schoolnet.

[21] Iqbal, M.; Ahmed, M. (2010). Enhancing quality of education through e-learning: the case study of Allama Iqbal Open University. The Turkish Online Journal of Distance Education, 11(1). Retrieved January 28, 2015 from https://tojde.anadolu.edu.tr/tojde37/articles/article_5.htm

[22] UNESCO. (2013). Information and communication technology (ICT) in education in five Arab states - a comparative analysis of ICT integration and e-readiness in schools in Egypt, Jordan, Oman, Palestine and Qatar. UNESCO Institute for Statistics, Succursale Centre-Ville Montreal, Ref: UIS/2013/ICT/TD/01/REV.3.

[23] Ukpai, U. (2013). Information communication technology in accounting Education: challenges and prospects. Journal of Education and Policy Review, 5(2), pp. 1-12. 
[24] Matheos, K. (2004). Effective Teaching with Technology in Higher Education. Teachers College Record, 106(5), pp. 938-940.

[25] Elsaadani, M. 2012. Exploration of Teaching Staff and Students' Preferences of Information and Communication Technologies in Private and Academic Lives. International Journal of Computer Science Issues (IJCSI), 9(2), pp. 396-402.

[26] Educational Testing Service. (2002). Digital Transformation: A Framework for ICT Literacy, Princeton, NJ: Author. Available from: http://www.ets.org/research/ictliteracy [accessed January 22, 2015].

[27] Longanecker, D. (2004). The Perfect Storm in Higher Education. Spectrum, 77(4), pp. 22-25.

[28] Jebeile, S.; Abeysekera, I. (2010). The spread of ICT innovation in accounting education. International Journal of Teaching and Learning in Higher Education, 22(2), pp 158-168.

[29] Valentine, G.; Marsh, J.; Pattie, C. (2005). Children and young people's home use of ICT for educational purposes: the impact on attainment at key stage 1-4. University of Leeds. Available at: www.dfes.gov.uk/research/data/uploadfiles/rr672.pdf (accessed 28 January 2015).

[30] Bui, B.; Porter, B. (2010). The Expectation-Performance Gap in Accounting Education: An Exploratory Study. Accounting Education: an international journal, 19, (1-2), pp. 23-50.

[31] Myunghee, K.; Heeok, H.; Minjeong, K. (2011). The impact of ICT use on new millennium learners' educational performance. Interactive Technology and Smart Education, 8(1), pp. 18-27.

[32] Tudor, C.; Gheorghe, M.; Oancea, M.; Sova, R. (2013). An analysis framework for defining the required IT\&C competencies for the accounting profession. Accounting and Management Information Systems, 12(4), pp. 671-696.

[33] Rhodes, N. (2013). The Future of Accounting Education with the Integration of ICT. International Conference - The Future of Education, 3rd Edition, Pixel, Florence, Italy, 13-14 June.

[34] Johnson, L.; Johnson, V. (1995). Help wanted - Accountant: What the Classifieds say about employers' expectations. Journal of Education for Business, 70(3), pp. 130-134.

[35] Rhodes, N. (2012). Transforming accounting education: Closing the gap between technology, education and accounting in higher education institutions. Ph.D. thesis, University of Johannesburg.

[36] Wessesls, P. (2007). An analysis of the current IT education offered to accounting students at South African universities. South African Journal of Accounting Research, 21(1), pp. 103-126.

[37] Asonitou, S. (2014). Employability Skills in Higher Education and the Case of Greece. International Conference on Strategic Innovative Marketing, IC-SIM 2014, September 1-4, Madrid, Spain.

[38] Lai, M. (2008). Technology readiness, internet self-efficacy and computing experience of professional accounting students. Campus-Wide Information Systems, 25(1), pp. 18-29.

[39] Schwartz, B.; Stout, D. (2001). A comparison of practitioner and educator opinions on tax education requirements for undergraduate accounting majors. Issues in Accounting Education, 2, pp. 112-126.

[40] Miller, A.; Woods, C. (2000). Undergraduate tax education: a comparison of educators' and employers' perceptions in the UK. Accounting Education, 9(3), pp. 223-241.

[41] Tan, L.; Veal, J. (2005). Tax knowledge for undergraduates accounting majors: conceptual vs. technical. Journal of Tax Research, 3(1), pp. 28-44.

[42] Juchau, R.; Neale, R. (2001). Taxation in Australian undergraduate accounting courses: a review and case note. Accounting Education, 10(1), pp. 27-36.

[43] Ekpenyong, L.; Ogbeide, I.; Owenvbiugie, R. (2012). Emerging challenges in Information and communication technology in Business Education. ABEN Book of Readings, 2 (1), pp. 8-16.

[44] Egbri, J. (2012). Assessment of the use of ICT in the teaching and learning of Business Education in University of Benin. Business Education Journal, VIII (2), pp. 290-303.

[45] Meade, J. (2002). Changes in the learning environment of tax education. The Tax Adviser, 2, pp. 130134.

[46] Rubin, J. (1999). Tax practitioners' response to education survey. The Tax Adviser, 30(11), pp. 806808.

[47] Howieson, B. (2003). Accounting practice in the New Millennium: is accounting education ready to meet the challenge? The British Accounting Review, 35, pp. 69-103.

[48] Engelbrecht, E. (2005). Adapting to changing expectations: postgraduate students' experience of an elearning tax program. Computers \& Education, 45, pp. 217-29.

[49] Ling, L.; Nawawi, N. (2010). Integrating ICT skills and tax software in tax education: A survey of Malaysian tax practitioners' perspectives. Campus-Wide Information Systems, 27(5), pp. 303-317.

[50] Dresnack, W.; Briggs, G. (2002). AICPA MTC in graduate accounting programs. The Tax Adviser, November, pp. 734-737. 
International Journal of Advanced Information Technology (IJAIT) Vol. 5, No. 1/2, April 2015

[51] Baharun, R.; Suleiman, E.; Simpol, M. (2006). What employers want from the graduates? Accountants Today, 4, pp. 38-41.

[52] Lin, Z.; Xiong, X.; Liu, M. (2005). Knowledge base and skill development in accounting education: evidence from China. Journal of Accounting Education, 23, pp. 149-169.

[53] American Assembly of Collegiate Schools of Business (AACSB). (1993). Achieving Quality and Continuous Improvement through Self-Evaluation and Peer Review: Standards for Business and Accounting Accreditation: Guidance for Self-evaluation. American Assembly of Collegiate Schools of Business.

[54] Institute of Management Accountants (IMA). (1996). The Practice Analysis of Management Accounting. Institute of Management Accountants.

[55] American Institute of Certified Public Accountants (AICPA). (1998). AICPA core competency framework for entry into the accounting profession. American Institute of Certified Public Accountants.

[56] American Accounting Association (AAA). (1986). Future Accounting Education: Preparing for the Expanding Profession. American Accounting Association, Committee on the Future Structure, Content, and Scope of Accounting Education (The Bedford Committee), Spring.

[57] Accounting Education Change Commission (AECC). (1990). Objectives of education for accountants: position statement number one. Issues in Accounting Education, 5(2), pp. 307-312.

[58] International Federation of Accountants Education (IFAC). (2003). International Education Guideline - IEG 11: Information technology for professional accountants Information Technology for Professional Accountants. International Federation of Accountants Education Committee.

[59] Chen, J.; Damtew, D.; Banatte, J.; Mapp, J. (2009). Information technology competencies expected in undergraduate accounting graduates. Research in Higher Education Journal, 3, pp. 1-7.

[60] Sanusi, M. (2011). Issues of Information Management in Nigerian Educational System. Journal of Business Educational Research and Development (JOBERD), 2(1), pp. 108-114.

[61] Stoner, G. (1999). IT is part of youth culture, but are accounting graduates confident in IT? Accounting Education, 8(3), pp. 217-237.

[62] Burnett, S. (2003). The future of accounting education: a regional perspective. Journal of Education for Business, 78(3), pp. 129-134.

[63] Slavin, R. (1992). Research on cooperative learning: consensus and controversy. In Collaborative Learning: A Sourcebook for Higher Education, Vol. II. (pp. 97-104). University Park: The National Center on Postsecondary Teaching, Learning, and Assessment (NCTLA).

\section{AUTHOR}

As an assistant professor of Information Systems and Creative Technologies at the Arab academy for Science and Technology since 1994, Dr. Elsaadani obtained his PhD degree from University of the West of England in 2010. He has several research papers, as well as nationally and internationally published books in the field of IS and ICT. Dr. Elsaadani is a professional consultant and human development trainer in the wide field of Business. He has a diverse profile with almost 22 years' experience in teaching/instructing, program developing,

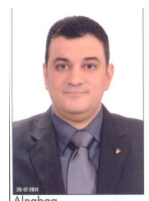
academic coordination, and as a senior executive in a multinational academic organizations in both Egypt and Kingdom of Bahrain. Moreover, his wide experience is shared among both enterprises and academia. 